\title{
Effects of an ecological conservation and restoration project in the Three-River Source Region, China
}

\author{
SHAO Quanqin, CAO Wei, FAN Jiangwen, "HUANG Lin, XU Xinliang
}

Key Laboratory of Land Surface Pattern and Simulation, Institute of Geographic Sciences and Natural Resources Research, CAS, Beijing 100101, China

\begin{abstract}
The first-stage of an ecological conservation and restoration project in the Three-River Source Region (TRSR), China, has been in progress for eight years. However, because the ecological effects of this project remain unknown, decision making for future project implementation is hindered. Thus, in this study, we developed an index system to evaluate the effects of the ecological restoration project, by integrating field observations, remote sensing, and process-based models. Effects were assessed using trend analyses of ecosystem structures and services. Results showed positive trends in the TRSR since the beginning of the project, but not yet a return to the optima of the 1970s. Specifically, while continued degradation in grassland has been initially contained, results are still far from the desired objective, 'grassland coverage increasing by an average of $20 \%-40 \%$ '. In contrast, wetlands and water bodies have generally been restored, while the water conservation and water supply capacity of watersheds have increased. Indeed, the volume of water conservation achieved in the project meets the objective of a 1.32 billion $\mathrm{m}^{3}$ increase. The effects of ecological restoration inside project regions was more significant than outside, and, in addition to climate change projects, we concluded that the implementation of ecological conservation and restoration projects has substantially contributed to vegetation restoration. Nevertheless, the degradation of grasslands has not been fundamentally reversed, and to date the project has not prevented increasing soil erosion. In sum, the effects and challenges of this first-stage project highlight the necessity of continuous and long-term ecosystem conservation efforts in this region.
\end{abstract}

Keywords: Three-River Source Region; ecological conservation and restoration; ecosystem monitoring and assessment; ecological effects

\section{Introduction}

The continued degradation of ecosystems in the Three-River Source Region (TRSR) as a

Received: 2016-03-03 Accepted: 2016-06-03

Foundation: National Nature Sciences Foundation of China, No.41571504; National Key Technology Research and Development Program, No.2013BAC03B00

Author: Shao Quanqin (1962-), Professor, E-mail: shaoqq@igsnrr.ac.cn

"Corresponding author: Huang Lin (1981-), PhD and Associate Professor, E-mail: huanglin@igsnrr.ac.cn 
result of the combined effects of climate change and human activities has been of major concern to the community. Indeed, with this in mind, the State Council approved 'The general planning on ecological conservation and restoration in the TRSR nature reserve in Qinghai Province' (abbreviated here to 'The Plan') in 2005, and decided to invest RMB 7.5 billion yuan in undertaking the first stage of the project (PGQP, 2003), aimed at curbing ecological deterioration in conservation areas, improving and consolidating the results of ecological conservation and restoration, and laying the foundations for later, large-scale implementation of ecological conservation and restoration. Thus, a comprehensive scientific understanding of the ecological effects of the project to date is critical for further effective implementation and scientific management of 'The Plan'.

A large number of similar domestic and foreign ecological monitoring and assessment projects have been carried out, including the United Nations Millennium Ecosystem Assessment (MA) program which proposed new concepts in ecological assessment, and established a conceptual framework for assessing ecosystem services, based on qualitative judgments of literature (MEA, 2003). In the US, ecosystem condition assessments have been carried out at the national scale using indicators including distributions and patterns of ecosystems, chemical and physical characteristics, products and services, landscape pattern, and the species present in ecosystems (Heinz Center, 2008). Since 2011, on the basis of these data, the US has been developing a 'National Ecological Observatory Network' (NEON) to monitor the biosphere (Abbot et al., 2015). Also in North America, Canada has developed an ecological monitoring and assessment network to assess the state of the environment based on long-term observational data (Vaughan et al., 2001). In China, ecological quality has been typically quantified using weight and normalization methods, as well as indicators including biological abundance, vegetation coverage, water network density, land degradation, and pollution load. These approaches are simple, but they lack key indicators of ecosystem services (CNEMC, 2004; EPIS of PRC, 2006; Li et al., 2006). Also, a series of systematic ecological assessments have been carried out at different scales from site to regional, such as the 'Western Ecosystem Comprehensive Assessment'; however, a systematic and comprehensive evaluation system has not been developed yet (Liu et al., 2006; Guo et al., 2016).

Internationally, key ecological projects stemmed from the 'Roosevelt Project' initiated in the US in 1934, including a range of initiatives carried out later around the world, such as the 'Stalin Plan for Reforming Nature' in the Former Soviet Union, the 'Green Dam Project' in North Africa, the 'Green Plan' in Canada, the 'Watershed Management Plan' in Japan, the 'Forestry Ecological Engineering' project in France, the 'National Afforestation Program' in the Philippines, the 'Social Forestry Program' in India, the 'Green Watershed Management Plan' in South Korea, and the 'Southern Himalayas Ecological Restoration Project' in Nepal (Li, 2007). Evaluation of these ecological restoration projects began in the 1950s as the Soviet Union, the United States, France, and Japan carried out evaluations of forest ecological services on the basis of in situ observations and other approaches (Xu, 1992; Wang et al., 2000), to analyze the ecological, economic, and social benefits from a sustainable development perspective (Liu, 2006). Subsequently, evaluation of the effects of ecological projects has evolved from the use of qualitative to more quantitative approaches.

China first carried out a pilot evaluation on the comprehensive effects of forestry ecological engineering in 1989. Since then, a series of systems of evaluation have been devel- 
oped for the 'Three-North Shelter Forest Program', the 'Grain for Green Project', the 'Natural Forest Protection Project', and other major ecological initiatives. Specifically, the normalized difference vegetation index (NDVI) and vegetation coverage (Cai, 2009), the amount and value of ecosystem services (SFA, 2014), as well as other ecological service indexes, including water regulation, soil and water conservation, sand-fixing, microclimate improvement, and agricultural non-point source pollution control (Yu et al., 2010; Xiao et al., 2012) have all been used to evaluate the effects of ecological projects in China. Subsequently, methods including empirical investigation, analytic hierarchy processing, and ecosystem value estimation have been widely adopted in China as part of ecological evaluation process (Hu et al., 2010). National standards for the evaluation of ecological projects have also been enacted (i.e. National Standards of the P.R.C., 2009; SFA, 2015), and national evaluation reports on project effectiveness have been released (SFA, 2014). However, existing assessments of ecological projects lack systematic index systems; thus, it is not currently possible to assess how well projects meet the targets set at initiation. A further widespread issue is that many existing efforts tend to use just the single year before project implementation as the 'baseline', rather than considering a longer-term, or more stable background. In many cases, this leads to an inaccurate assessment of project effects.

Thus, in order to effectively evaluate the ecological effects of the first-stage project in the TRSR, we improved the study in three aspects. First, an integrated approach was taken by combining in situ observations with remote sensing, and process-based models. Second, a comprehensive index system for the evaluation of ecological effect was proposed that takes ecosystem structure, quality, and services into account. Third, 'dynamic process of ecological background' were used for evaluation. Overall, our evaluation is expected to quantify the effects of the ecological restoration project, and to provide scientific support for the future of this conservation and restoration project as it moves into a second phase.

\section{Materials and methods}

\subsection{Study area}

The TRSR is located in the hinterland of the Qinghai-Tibet Plateau. As the source region for the Yangtze, Yellow, and Lancang rivers, which together supply about 40 billion $\mathrm{m}^{3}$ of water downstream each year, the TRSR is often referred to as the 'Chinese water tower'. The region covers an area of $363,000 \mathrm{~km}^{2}$, with grassland, wetland, forest, and cropland accounting for $65 \%, 8.5 \%, 4.7 \%$, and $0.3 \%$ of the regional total area, respectively (Xu et al., 2008). Grassland in this region is mainly comprised of alpine meadow and alpine grassland, which accounts for $76 \%$ and $23 \%$ of the total grassland area, respectively. The first stage of the TRSR ecological conservation and restoration project, implemented between 2005 and 2012, comprised 22 sub-projects classified into three categories: ecological protection, construction of infrastructure to support the livelihood and productivity of farmers and herdsmen, and supporting projects. Overall, the project implementation area included 18 nature reserves (Figure 1), covering an area of $152,300 \mathrm{~km}^{2}$, accounting for $21 \%$ of the total area of Qinghai Province, and $42 \%$ of the TRSR, respectively. 


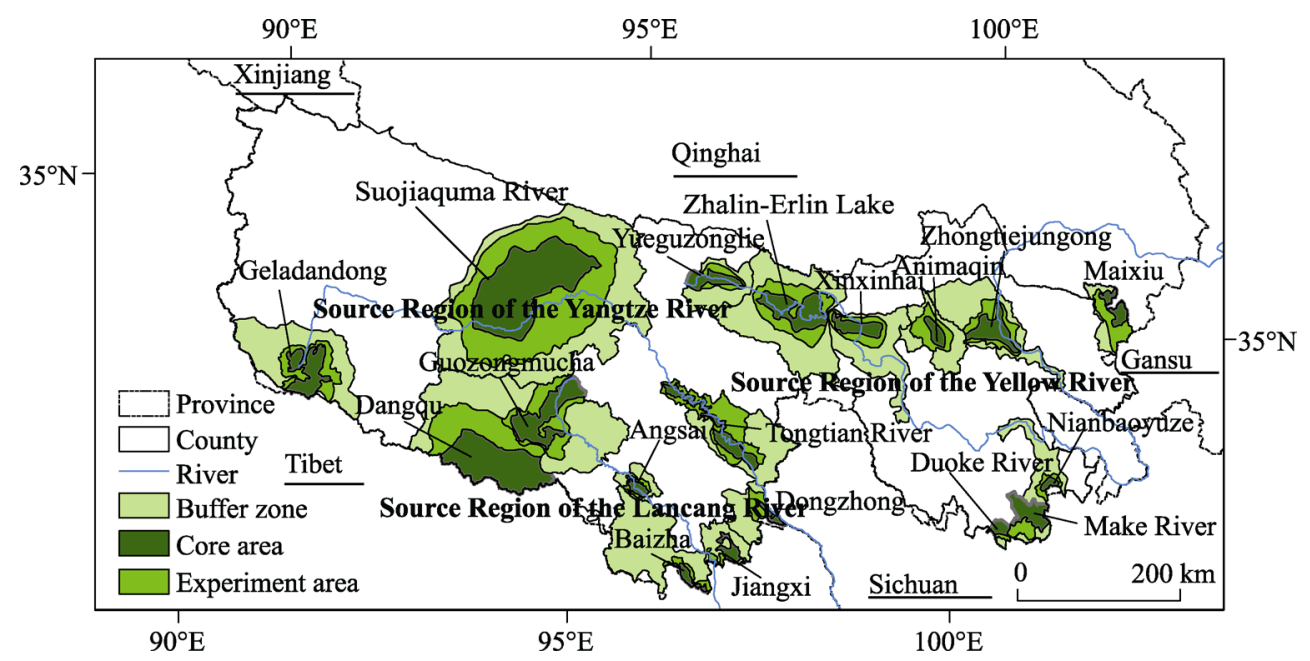

Figure 1 Distribution map of nature reserves in the TRSR, Qinghai Province, China

\subsection{Assessment index system}

In terms of scientific applicability and operability, the index series used for assessing the effects of this project was built based around the integrated assessment indicator system for grassland ecosystems in the TRSR (Liu et al., 2009), as well as a local standard, 'technical specification of ecological effects assessment of ecosystem protection and recovery projects in the TRSR' (LSQP, 2014), developed when planning the targets of this ecological project. As outlined in Table 1, the index series included four major criteria groups broken down into 15 first class, and 75 second class indexes (Table 1).

\subsection{Data acquisition and processing}

\subsubsection{Ground monitoring and field observation}

The terrestrial ecosystem monitoring system for the TRSR encompasses 492 sites (Figure 2) that are mainly used to monitor changes in different ecosystems (e.g. grassland, forest, wetland, and desert), hydrology and water resources, soil conservation, meteorological elements. In total, millions of observational data points regarding vegetation productivity, plant compositional structure, soil properties, grassland degradation, hydrology, and meteorology were acquired between 2005 and 2012 by this monitoring system. In addition, during the course of project implementation, a great deal of fieldwork was also conducted, including surveys for remote sensing interpretation and verification of land use and cover change (LUCC) and grassland degradation (Liu et al., 2008; Xu et al., 2008), sampling surveys to measure the water holding capacity of soil, soil erosion ${ }^{137} \mathrm{Cs}$ (Shao et al., 2011; Sun et al., 2011), investigations of soil physical and chemical properties, grassland plots to investigate and verify grassland productivity and grass yield simulation results (Fan et al., 2010; Wang et al., 2010), as well as cyclic sampling data collected from five, large $5 \mathrm{~km}^{2}$ plots that were interrogated using remote sensing and ground-scale transformation (Bing et al., 2012). 
Table 1 Index series used for assessment of the ecological effect of the TRSR ecological projection and restoration project

\begin{tabular}{|c|c|c|}
\hline \multirow{2}{*}{ Category of index } & \multicolumn{2}{|r|}{ Evaluation index } \\
\hline & First class indexes & Second class indexes \\
\hline \multirow{2}{*}{$\begin{array}{l}\text { Ecosystem } \\
\text { macrostructure }\end{array}$} & Ecosystem macrostructure & Ecosystem classification area, rate of change, dynamic degree \\
\hline & \multicolumn{2}{|c|}{ Ecosystem macroscopic structural change index } \\
\hline \multirow{7}{*}{ Ecosystem quality } & $\begin{array}{l}\text { Grassland degradation and } \\
\text { recovery }\end{array}$ & $\begin{array}{l}\text { Grassland degradation and recovery classification area, propor- } \\
\text { tion of degraded grassland and recovered grassland, grassland } \\
\text { degradation change index }\end{array}$ \\
\hline & Vegetation status & $\begin{array}{l}\text { Vegetation biomass, vegetation coverage, net primary productiv- } \\
\text { ity (NPP), vegetation change condition index }\end{array}$ \\
\hline & Macro-ecological situation & Land cover status index, land cover conversion index \\
\hline & Plant species diversity & $\begin{array}{l}\text { Species richness, species importance value, diversity index, } \\
\text { evenness index }\end{array}$ \\
\hline & Environmental quality & $\begin{array}{l}\text { Surface water quality index, soil environmental quality index, air } \\
\text { quality index }\end{array}$ \\
\hline & \multicolumn{2}{|c|}{ Upper limit of permafrost depth } \\
\hline & \multicolumn{2}{|c|}{ Ecosystem quality change index } \\
\hline \multirow{5}{*}{$\begin{array}{l}\text { Ecosystem } \\
\text { services }\end{array}$} & Water regulation & $\begin{array}{l}\text { River runoff in dry season, water regulation volumes, water reg- } \\
\text { ulation service retention, river runoff in summer flood season, } \\
\text { runoff adjustment coefficient }\end{array}$ \\
\hline & Soil conservation & $\begin{array}{l}\text { Sediment concentration, soil erosion, soil retention, soil conser- } \\
\text { vation service }\end{array}$ \\
\hline & Forage supply & Grassland yield, grassland theoretical stock-carrying capacity \\
\hline & Water supply & $\begin{array}{l}\text { River runoff, lake area, lake volume, glacier area, ground water } \\
\text { resources }\end{array}$ \\
\hline & \multicolumn{2}{|c|}{ Ecosystem services change index } \\
\hline \multirow{5}{*}{$\begin{array}{l}\text { Ecosystem } \\
\text { change factors }\end{array}$} & Climate change & Temperature, precipitation, wet coefficient \\
\hline & Human activities & Ecological project, grazing pressure index \\
\hline & \multirow{3}{*}{$\begin{array}{l}\text { Contributions influenced } \\
\text { by ecological project and } \\
\text { climate change }\end{array}$} & Ecosystem project changes influence index \\
\hline & & $\begin{array}{l}\text { Contributions to NPP change, water regulation service, soil con- } \\
\text { servation service, sand fixing service influenced by ecological } \\
\text { project }\end{array}$ \\
\hline & & $\begin{array}{l}\text { Contributions to NPP change, water regulation service, soil con- } \\
\text { servation service, sand fixing service influenced by climate } \\
\text { change }\end{array}$ \\
\hline
\end{tabular}

\subsubsection{Remote sensing interpretation and parameter inversion}

Landsat MSS and TM images taken in the 1970s, the 1990s, in 2004, and by the HJ satellite in 2012 were interrogated to interpret LUCC on the basis of earth science, climatology, and ecological data (Xu et al., 2008). Thus, on this basis, we generated spatial datasets for forests, grasslands, croplands, wetlands and water, settlements, and other ecosystems, and analyzed the temporal and spatial dynamics of each ecosystem. Spatial data at the 1:100,000 scale for grassland degradation, and trends in degraded grassland ecosystems, in the TRSR between the 1970s and 1990s, and between the 1990s and 2004, were produced using the remote sensing grassland degradation/restoration classification system and by taking both 


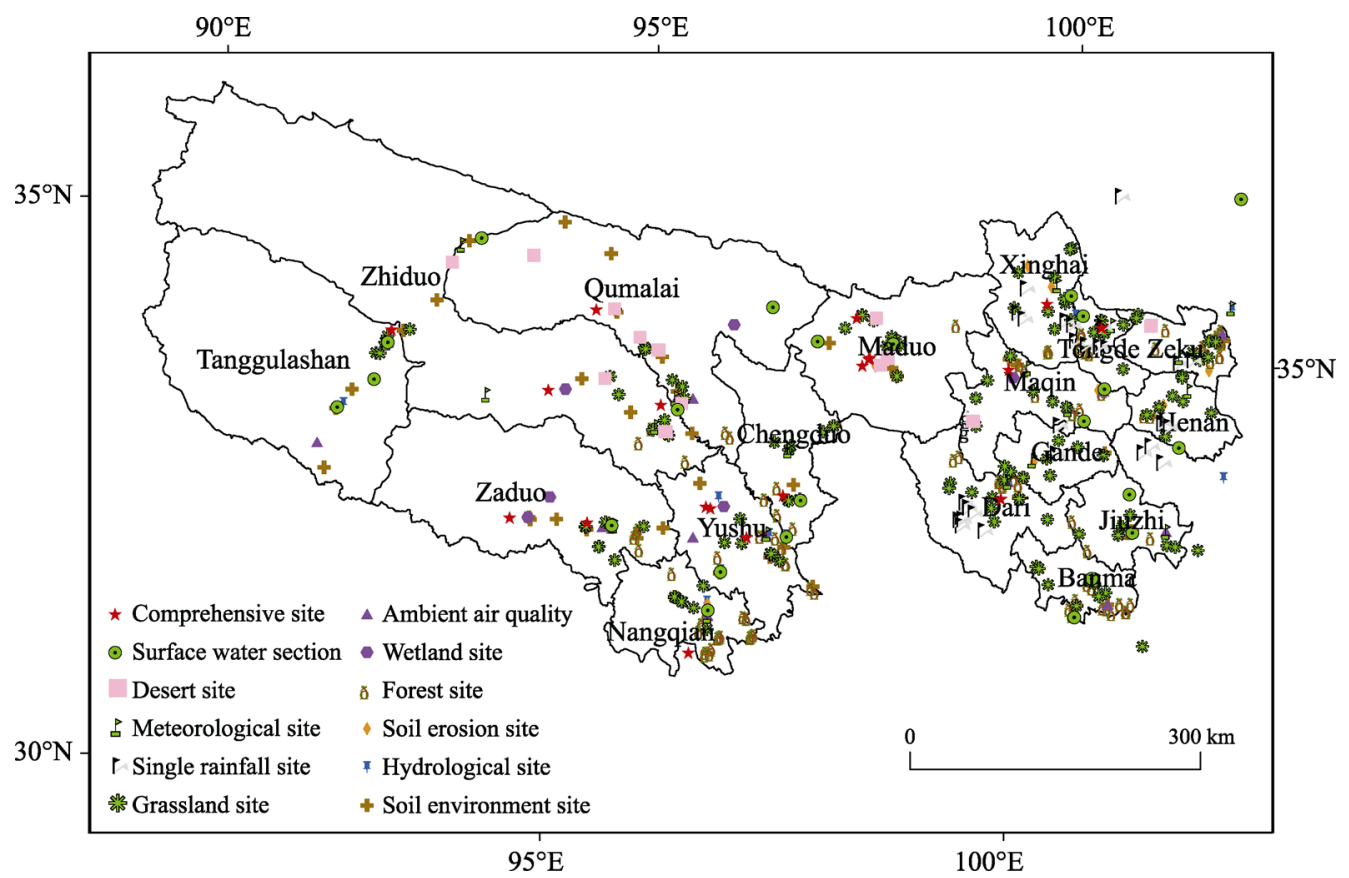

Figure 2 Distribution map of ecosystem field monitoring networks in the TRSR

forms and causes into account (Liu et al., 2008). Thus, the existing land use dynamic index model was improved and developed into an ecological situation change index (i.e. a land cover conversion index) (Zhao et al., 2010) that was then used to quantify the changing status as the ecosystems.

\subsubsection{Model simulation}

The Global Production Efficiency Model (GLOPEM) was augmented and used in this study, with model parameters localized using large plot data obtained by cyclic sampling (Wang et al., 2010). Specifically, the NDVI at three different scales (TM $30 \mathrm{~m}$, MODIS $250 \mathrm{~m}$, and 1 $\mathrm{km}$ ) was used to verify the results of model parameters and simulations by establishing conversion relationships between the three scales (Chen et al., 2012). NPP data at 16-day intervals and at $1 \mathrm{~km}$ spatial resolution within the TRSR between 1988 and 2012 were simulated, and grassland types, seasonal pasture zones, livestock statistics, earliest survey of grassland resources, and monitoring data on grassland resources in the TRSR were input to simulate grassland yield and the grazing pressure index using GLOPEM, the Underground Productivity Model (Fan et al., 2010), and the algorithm of the Grazing Pressure Index (Fan et al., 2011).

The precipitation storage method was used to simulate the water regulation capacity of forests, grasslands, and wetland ecosystems in the TRSR. Specifically, an improved K-value correction method was developed to avoid spatial disparities by using ground surveys, remote sensing, meteorological data, and average river runoff on a year-by-year basis. Indeed, using runoff data, the efficiency coefficient $\mathrm{R}$ was determined, which denotes the runoff reduction capacity of an alpine meadow ecosystem compared to bare land ( $\mathrm{Wu}, 2014)$.

Water erosion in the TRSR was calculated using the Revised Universal Soil Loss Equation (RUSLE) (Renard et al., 1997). For this analysis, parameters in RUSLE including the 
rainfall erodibility factor $(\mathrm{R})$, the soil erodibility factor $(\mathrm{K})$, slope length and steepness factor (LS), the cover-management factor (C), and the support practice factor (P) were all localized. Intervals for rainfall erodibility and grassland coverage factors were set to 16 days to avoid time asynchronism. An observational dataset containing annual sediment concentrations from four major hydrological stations in the Yangtze and Yellow rivers was used for validating the results of RUSLE, and the $R^{2}$ was set to 0.72 .

\subsection{Project ecological effects}

As part of this assessment, we proposed the concept of a 'dynamic process of ecological background', in which we consider both the average ecosystem status 5-10 years before the start of the project, and trends in ecosystem change over the past 20-30 years, as an ecological background. As a result, this 'dynamic process of ecological background' solves the uncertainty in ecological effect assessment that is caused by periodicity of rainfall, helps to master changing processes in the ecosystem accurately, and enables scientific assessment of ecological restoration.

Based on the 'dynamic process of ecological background', both the objectives of the project, and a comprehensive assessment of the project ecological effects were carried out. Comparisons between average status and trends in many indicators, including ecosystem structure, quality and services, before, and after, the project, as well as inside, and outside, nature reserves were made. Simulated results in both average climate, and real climate, modes were generated and compared, and ecological effects were assessed in the context of climate change.

On the basis of the specific project assessment objectives, the evaluation period was divided into four categories: 30 years before the implementation of the project (mid-1970s to 2004), 14 years before the implementation of the project (1990-2004), eight years before the implementation of the project (1997-2004), and the project period (2004-2012).

\subsection{Factors contributing to ecosystem change}

Climate change and implementation of the TRSR ecological project are the main factors contributing to ecosystem change in this region. Thus, in order to determine the relative contributions of these two factors to ecosystem change, a number of datasets including NPP, soil erosion, and water regulation capability, simulated under both average and real climatic conditions, were compared. Results simulated on the basis of average climatic variables reflect the effects of the ecological project with climate factors excluded, while results simulated using real climatic variable are a synthesis both of climate change and the ecological project. Therefore, contribution rates of climate change and the ecological project to ecosystem change can be determined by contrasting the results under average climate conditions and real climate conditions before and after the implementation of the project (hereafter before and after the project). Specifically, separate contributions can be calculated as follows:

$$
\begin{gathered}
C_{\text {project }}=\frac{G_{A l}-G_{A p}}{G_{R l}-G_{R p}} \\
C_{\text {nature }}=1-C_{\text {project }}
\end{gathered}
$$


where $C_{\text {project }}$ denotes the contribution rate of the ecological project; $C_{\text {nature }}$ is the contribution rate of natural factors (dominated by climate change); $G_{A l}$ and $G_{A p}$ are indicator values after and before the project under average climate conditions; and $G_{R l}$ and $G_{R p}$ denote the indicator values after and before the project under real climatic conditions.

\section{Results}

\subsection{Macro-ecological change}

Since the implementation of the ecological project, water-bodies in the TRSR have been partially expanded, and former desert ecosystem has been partially transformed into grassland ecosystem. Indeed, the overall ecosystem structure has gradually developed in a benign direction; 30 years before the initiation of this project, the net decreases in grasslands and wetlands (including water-bodies) were $1389.9 \mathrm{~km}^{2}$ and $375.14 \mathrm{~km}^{2}$, respectively, while the net increase in desert was $674.38 \mathrm{~km}^{2}$. In contrast, over the 8 -year project period, grassland area has increased by $123.70 \mathrm{~km}^{2}$, wetland and water areas have increased by $279.85 \mathrm{~km}^{2}$, and the desert ecosystem has decreased by $492.61 \mathrm{~km}^{2}$. Use of the 'ecological situation change index' shows that, while the macro-ecological situation was getting worse over the whole area 30 years before the project, it improved over the course of the 8-year project period (Figure 3).

Annual average vegetation cover in 2005-2012 also improved markedly compared with the situation between 1998 and 2004. Indeed, vegetation cover increased in $79.18 \%$ of the TRSR, while just slightly, and obviously, improved areas accounted for $43.67 \%$ and $35.51 \%$, respectively (Figure 4).

\subsection{Trends in grassland degradation and recovery}

According to ecological background survey findings, the degradation pattern in the TRSR had been basically formed since the $1970 \mathrm{~s}$; around $40.1 \%$ of grassland in this region was degraded to different degrees between the 1970s and 2004. However, after this project, $68.52 \%$ of degraded grassland was unchanged, $24.85 \%$ was slightly improved, and $6.17 \%$ was greatly improved. Latest degradation represented $0.12 \%$, while areas of aggregated degradation represented only $0.34 \%$ (Figure 5).

From 1988 to 2004, the average amount of grass production in the TRSR was $533 \mathrm{~kg} / \mathrm{hm}^{2}$; these grasslands were also 1.42 times totally overgrazed, even reaching as much as 2.5 times overgrazed between the winter and spring. During the eight years of this project, grass production reached $694 \mathrm{~kg} / \mathrm{hm}^{2}$, about a 30.31\% increase, while 'ecological migration' and a reduction in livestock were implemented on some severely degraded grassland at an average reduction rate of $20 \%$. As a result of these two factors, the grazing pressure index decreased $36.1 \%$ (Figure 6).

From 2005 to 2012, vegetation coverage of natural grassland was $69 \%-83 \%$ and showed an increasing trend, especially in temperate steppe; this means that the degrading grassland trend in the TRSR was initially contained, and project implementation had both a direct and positive effect on grassland coverage. However, because it is very hard to improve alpine grassland areas as they are limited by temperature, precipitation, altitude, and other factors, the project goal to improve vegetation cover $20 \%-40 \%$ over the TRSR was not achieved. 

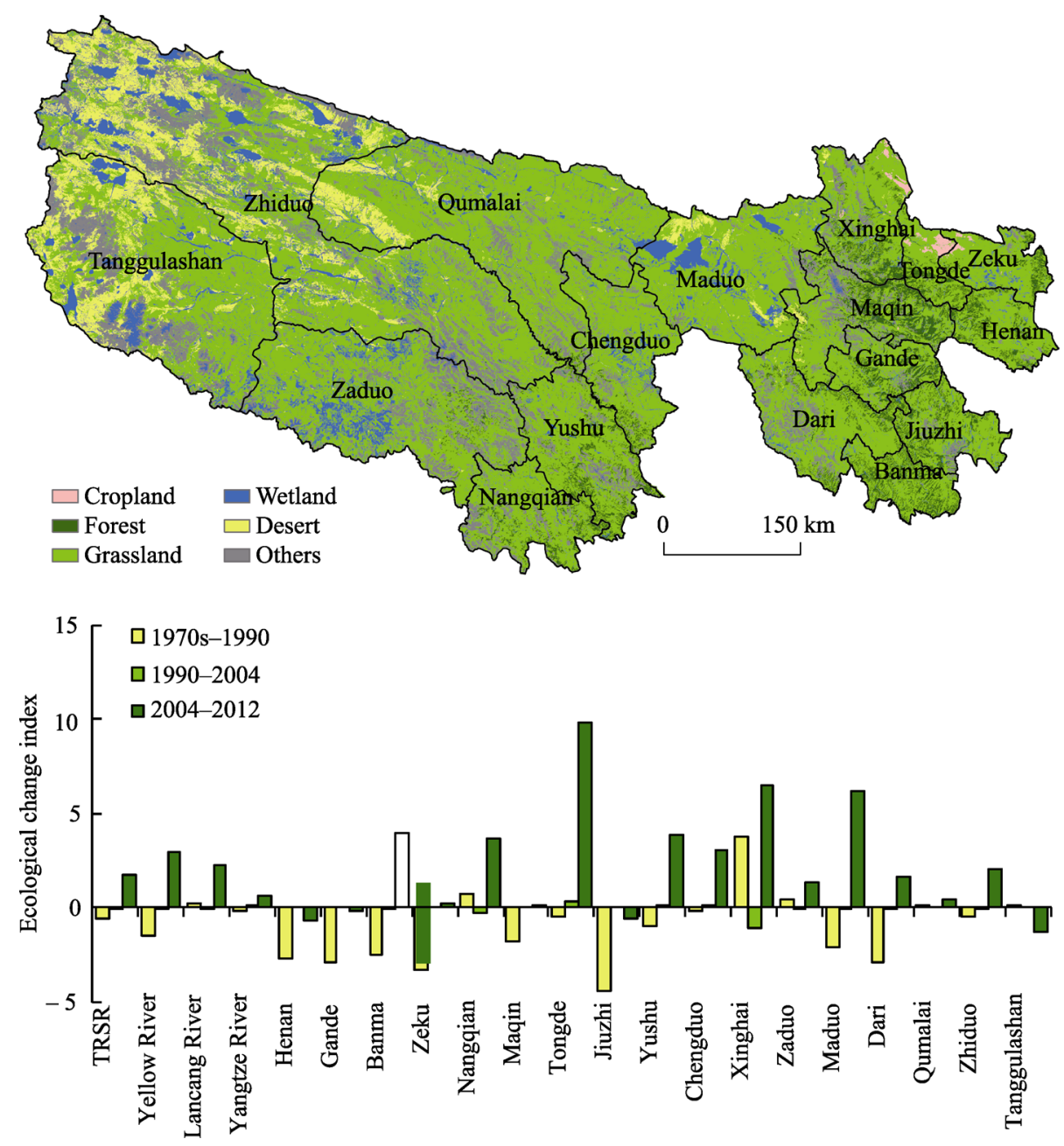

Figure 3 Distribution of ecosystem types in the TRSR in 2012, and the ecological change index from the 1970s to 2012

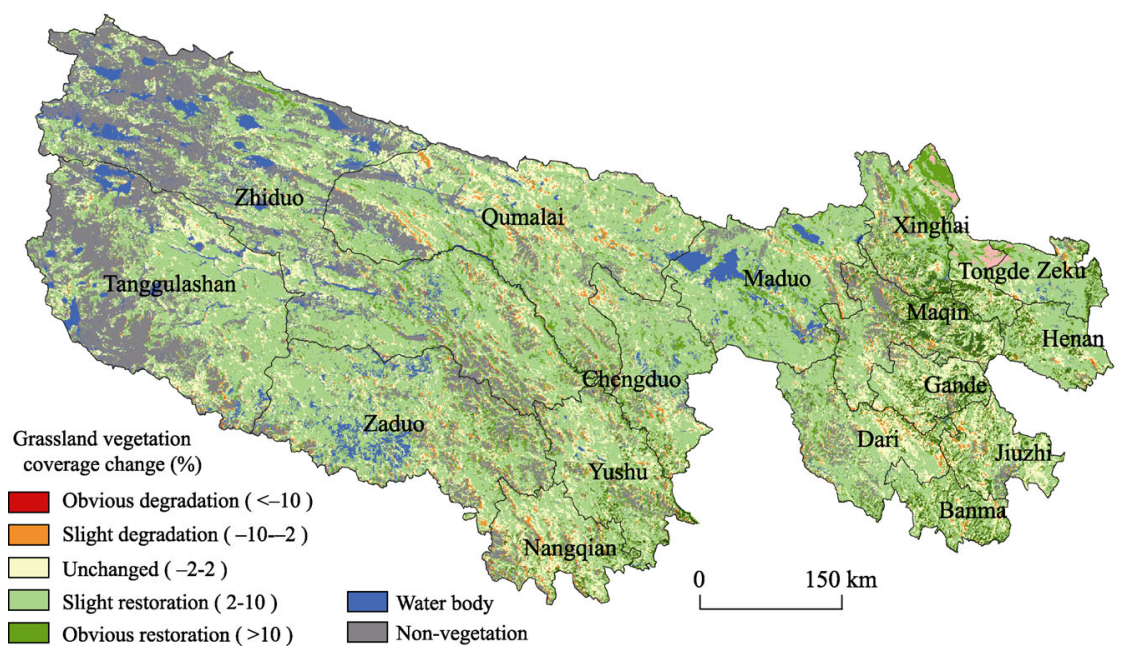

Figure 4 Changes in average vegetation cover before, and after, implementation of the TRSR project 

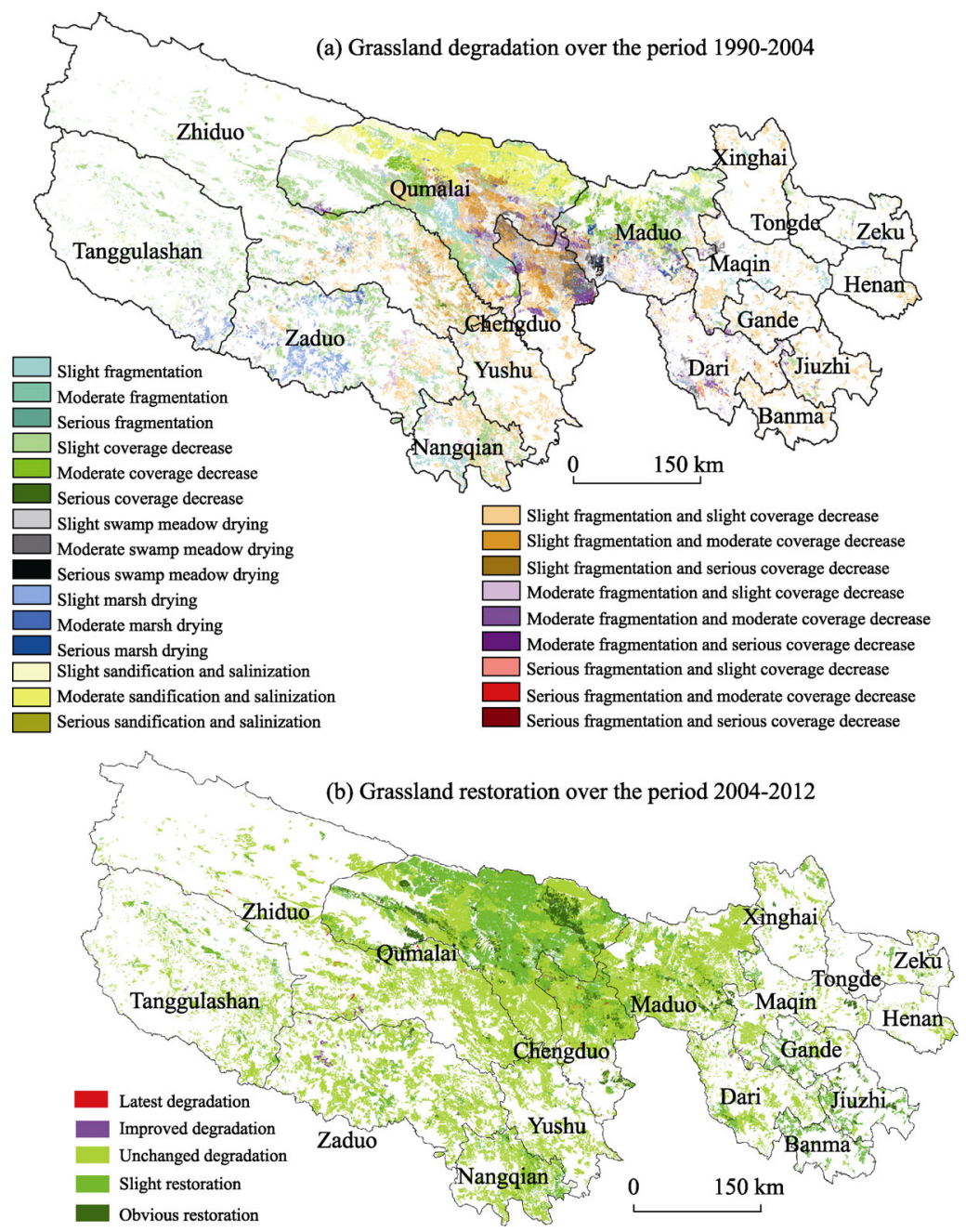

Figure 5 Distribution of degraded grassland in the TRSR over the period 1990-2004 (a), and grassland restoration over the period 2004-2012 (b)

\subsection{Water regulation and water supply services}

The water regulation services in forested and grassland ecosystems improved from 1997 to 2012 (Figure 7). Over this period, the average annual water regulation volume was 15.36 billion $\mathrm{m}^{3} / \mathrm{yr}$, while the per unit amount was $430.67 \mathrm{~m}^{3} / \mathrm{hm}^{2} / \mathrm{yr}$. From 1997 to 2004, the average annual water regulation volume in forested and grassland ecosystems was 14.249 billion $\mathrm{m}^{3}$, and the trend was 0.166 billion $\mathrm{m}^{3} / 10 \mathrm{yr}$. From 2005 to 2012 , the average annual water regulation volume increased $15.6 \%$, reaching 16.471 billion $\mathrm{m}^{3} / \mathrm{yr}$, while the variation trend was 1.93 billion $\mathrm{m}^{3} / 10 \mathrm{yr}$. In the Yangtze, Yellow, and Lancang river basins, water regulation volumes also improved as a result of the ecological project, showing increases of 923 million $\mathrm{m}^{3} / \mathrm{yr}, 1.048$ billion $\mathrm{m}^{3} / \mathrm{yr}$, and 130 million $\mathrm{m}^{3} / \mathrm{yr}$, respectively.

Overall, the net increase in water and wetlands in the TRSR from 2004 to 2012 was $279.85 \mathrm{~km}^{2}, 9.11 \%$ of that in 2004 . Water regulation volume also improved from 24.239 billion $\mathrm{m}^{3} / \mathrm{yr}$ to 24.424 billion $\mathrm{m}^{3} / \mathrm{yr}$ over this period. 


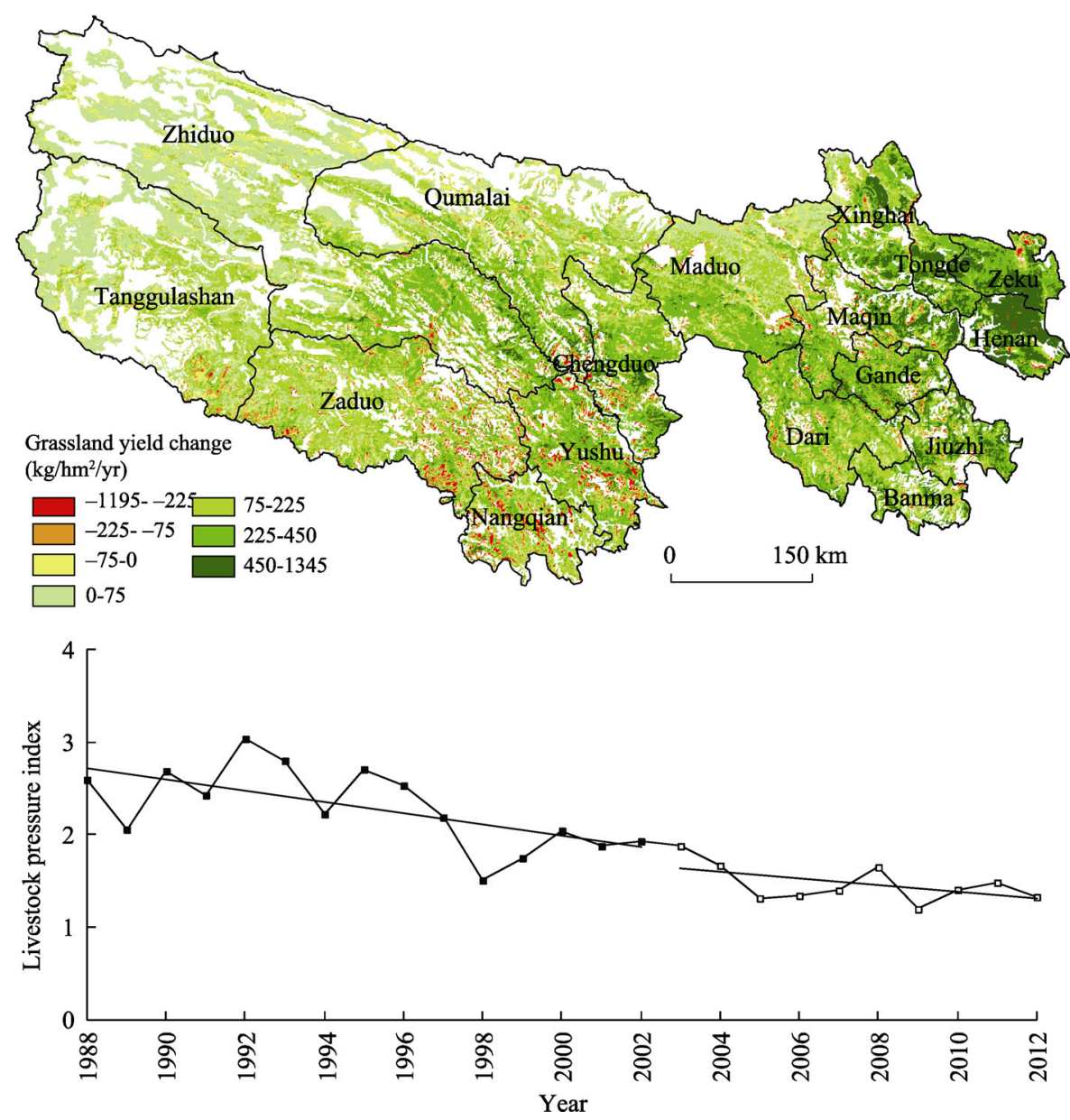

Figure 6 Comparative changes in grassland yield before, and after, implementation of this project, as well as annual variation in the livestock pressure index in the TRSR

The total increase in water regulation and water supply was around 2.41 billion $\mathrm{m}^{3}$, more than the project objective, an increase of 1.32 billion $\mathrm{m}^{3}$.

Of particular note, the annual runoff in the Yellow River Basin recovered remarkably compared with levels before the project, while the annual runoff at Tangnaihai and Jimai hydrological stations increased 3.69 billion $\mathrm{m}^{3}$ and 1.71 billion $\mathrm{m}^{3}$, respectively (Figure 8). Although this total increase in annual runoff was more than the project objective, an increase of 1.2 billion $\mathrm{m}^{3}$, the declining trend seen since the $1970 \mathrm{~s}$ had not yet been reversed. Indeed, runoff from the Tuotuohe hydrological station in the Yangtze River Basin has continued to increase as a result of climate warming and accelerated melting of snow and ice, while the annual runoff at Zhimenda hydrological station recovered fast, increasing 3.92 billion $\mathrm{m}^{3} / \mathrm{yr}$ (Figure 8) compared with before the project. Of particular note, the declining trend in annual runoff in the Yangtze River Basin has been initially curbed after a long time.

\subsection{Soil conservation services}

From 1997 to 2012, soil retention in the TRSR conformed to an upward trend, with an average annual value of 635 million t/yr (Figure 9). Indeed, due to vegetation recovery, soil 

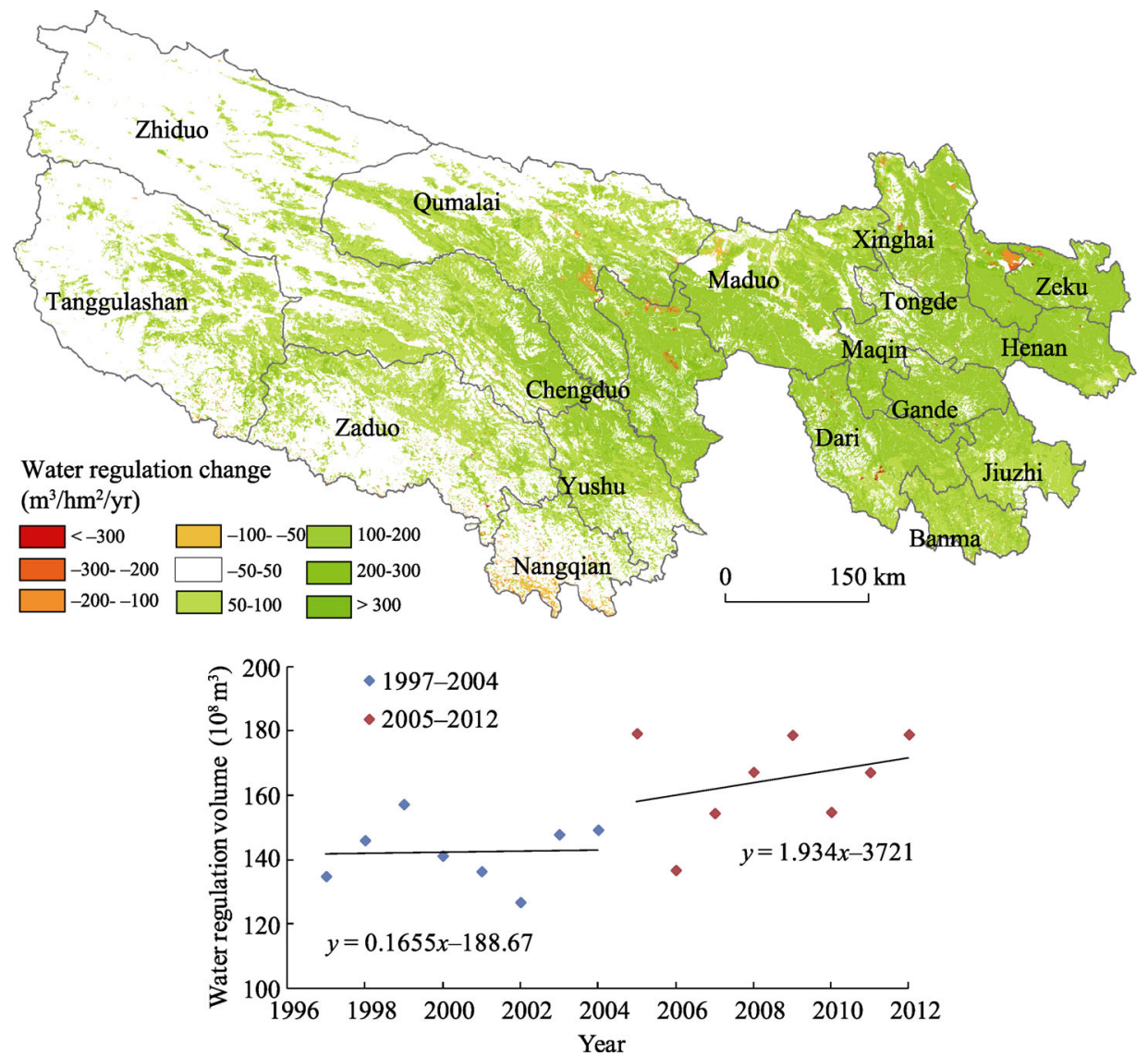

Figure 7 Changes and annual variation in water regulation volume of forested and grassland ecosystems in the period 1997-2012

(a) Tangnaihai hydrological station

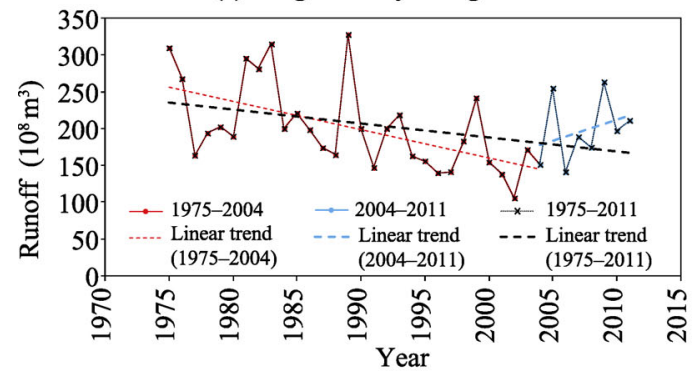

(c) Zhimenda hydrological station

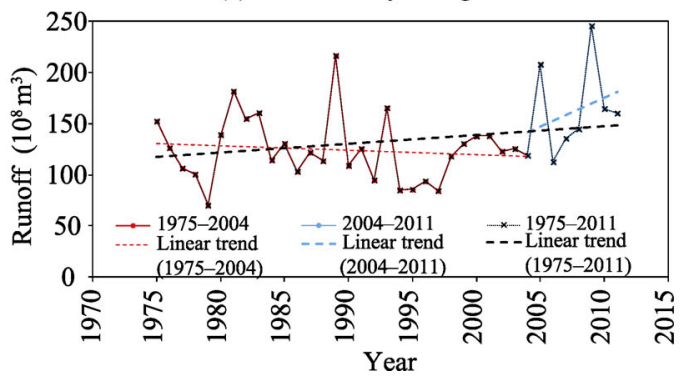

(b) Jimai hydrological station

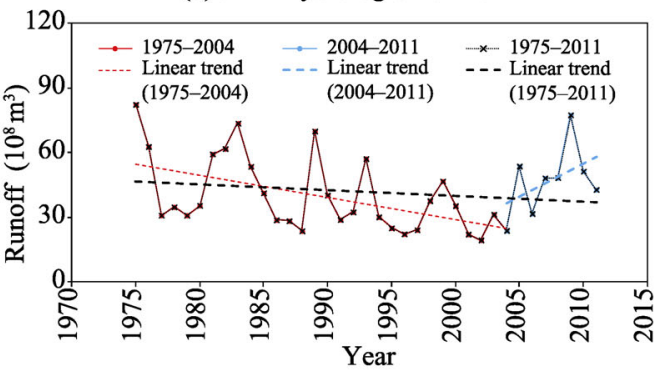

(d) Tuotuohe hydrological station

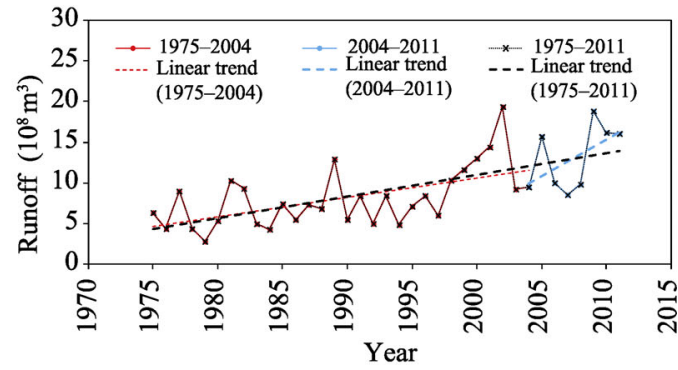

Figure 8 Annual total runoff at major hydrological stations in the source regions of the Yangtze and Yellow rivers 
conservation capacity has improved remarkably; average annual soil retention changed from 546 million t/yr to 723 million $\mathrm{t} / \mathrm{yr}$, a $32.5 \%$ increase. However, in spite of this, soil erosion still showed a slight upward trend from 1997 to 2012 (Figure 10); from 2005 to 2012, average annual soil erosion was 320 million tons, an increase of 20 million tons (16 million $\mathrm{m}^{3}$ )
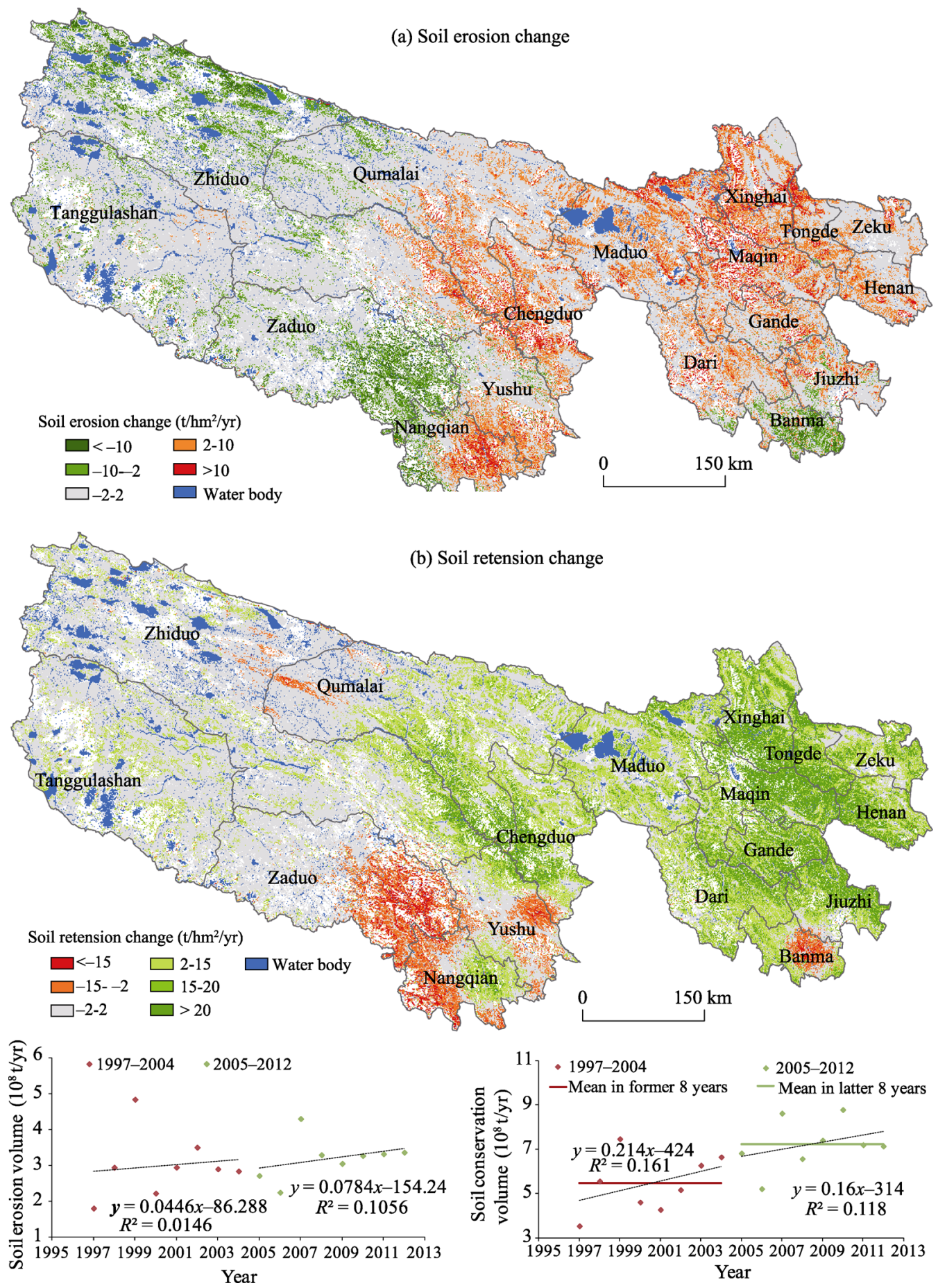

Figure 9 Changes, and annual variation, in soil erosion (a) and soil retention volume (b) in the period 1997-2012 
compared with 1997-2004. These data show that, in this regard, one objective of 'The Plan' was not achieved. Indeed, precipitation increased markedly from 2005 to 2012 in the TRSR, which not only helped vegetation recovery, but also led to an increase in rainfall erosivity, the main reason for the increase in soil erosion.

\subsection{Dynamic ecological status analysis of key project areas}

High quality ecosystems in the TRSR, including forests, grassland, wetland and water, decreased by $386 \mathrm{~km}^{2}$ from 1990 to 2014, while deserts and some other ecosystems increased by $389.2 \mathrm{~km}^{2}$. Indeed, outside the project area, high quality ecosystems saw a net decrease of $98.8 \mathrm{~km}^{2}$, while deserts and other ecosystems increased by $97.4 \mathrm{~km}^{2}$. From 2005 to 2012 , high quality ecosystems in the project area increased by $252.2 \mathrm{~km}^{2}$, more than the $173 \mathrm{~km}^{2}$ increase seen outside the project area. Deserts and other ecosystems decreased by $252.2 \mathrm{~km}^{2}$ inside the project area but by only $180.8 \mathrm{~km}^{2}$ outside the project area (Table 2).

Table 2 Changes in ecosystem area $\left(\mathrm{km}^{2}\right)$ inside, and outside the nature reserves before and after project implementation

\begin{tabular}{|c|c|c|c|c|c|c|c|}
\hline Period & Regions & Cropland & Forest & Grassland & Wetland & Desert & Others \\
\hline \multirow{2}{*}{$\begin{array}{c}1990-2004 \\
\text { (before the } \\
\text { project) }\end{array}$} & $\begin{array}{l}\text { Nature } \\
\text { reserves }\end{array}$ & -3.22 & -12.8 & -362.4 & -10.8 & +387.6 & +1.6 \\
\hline & $\begin{array}{l}\text { Outside nature } \\
\text { reserves }\end{array}$ & +1.32 & -0.7 & -83.4 & -14.7 & +43.8 & +53.6 \\
\hline \multirow{2}{*}{$\begin{array}{l}2004-2012 \\
\text { (after the } \\
\text { project) }\end{array}$} & Nature reserves & Unchanged & +12.1 & +135.2 & +104.9 & -192.1 & -60.1 \\
\hline & $\begin{array}{l}\text { Outside nature } \\
\text { reserves }\end{array}$ & +7.84 & +3.3 & -11.4 & +181.1 & -300.5 & +119.7 \\
\hline \multirow{3}{*}{$\begin{array}{l}\text { Compari- } \\
\text { son after } \\
\text { and before } \\
\text { the project }\end{array}$} & $\begin{array}{l}\text { Nature } \\
\text { reserves }\end{array}$ & $\begin{array}{l}\text { Reduced at } \\
\text { first then } \\
\text { unchanged }\end{array}$ & $\begin{array}{l}\text { Reduced } \\
\text { at first } \\
\text { then in- } \\
\text { creased }\end{array}$ & $\begin{array}{l}\text { Reduced } \\
\text { at first } \\
\text { then in- } \\
\text { creased }\end{array}$ & $\begin{array}{l}\text { Reduced } \\
\text { at first } \\
\text { then in- } \\
\text { creased }\end{array}$ & $\begin{array}{l}\text { Increased } \\
\text { at first } \\
\text { then } \\
\text { reduced }\end{array}$ & $\begin{array}{l}\text { Increased } \\
\text { at first then } \\
\text { reduced }\end{array}$ \\
\hline & $\begin{array}{l}\text { Outside } \\
\text { nature reserves }\end{array}$ & $\begin{array}{l}\text { Continu- } \\
\text { ously in- } \\
\text { creased }\end{array}$ & $\begin{array}{l}\text { Reduced } \\
\text { first } \\
\text { then in- } \\
\text { creased }\end{array}$ & $\begin{array}{l}\text { Continu- } \\
\text { ously } \\
\text { reduced }\end{array}$ & $\begin{array}{l}\text { Reduced } \\
\text { at first } \\
\text { then in- } \\
\text { creased }\end{array}$ & $\begin{array}{l}\text { Increased } \\
\text { at first } \\
\text { then re- } \\
\text { duced }\end{array}$ & $\begin{array}{l}\text { Continu- } \\
\text { ously } \\
\text { increased }\end{array}$ \\
\hline & $\begin{array}{l}\text { Comparison of } \\
\text { inside and } \\
\text { outside }\end{array}$ & $\begin{array}{l}\text { Inside is } \\
\text { better than } \\
\text { outside }\end{array}$ & $\begin{array}{l}\text { Inside is } \\
\text { better than } \\
\text { outside }\end{array}$ & $\begin{array}{l}\text { Inside is } \\
\text { better than } \\
\text { outside }\end{array}$ & $\begin{array}{l}\text { Inside is } \\
\text { better } \\
\text { than } \\
\text { outside }\end{array}$ & $\begin{array}{l}\text { Inside is } \\
\text { better than } \\
\text { outside }\end{array}$ & $\begin{array}{l}\text { Inside is } \\
\text { better than } \\
\text { outside }\end{array}$ \\
\hline
\end{tabular}

Note: '-' indicates decrease, '+' indicates increase; 'inside' indicates the reserve, 'outside' indicates outside the reserve.

From 1990 to 2004, the ecological change indexes of 18 nature reserves were all negative, showing that the ecological status of each nature reserve had decreased. Of these, the ecological change index of Animaqing was the worst, followed by Xingxinghai and Zaling-Eling Lake. However, in contrast, from 2004 to 2012, the ecological change indexes of all nature reserves were positive with the exception of Nianbaoyuze; these data show that ecological status has improved as a result of this project, especially in Xingxinghai, Zaling-Eling Lake, and Tongtian River (Figure 10).

From 1990 to 2004, the area of degraded grassland in nature reserves was $43490.67 \mathrm{~km}^{2}$, accounting for $49.4 \%$ of degraded grassland in the TRSR. However, from 2005 to 2012, this was improved markedly; areas of degraded grassland inside nature reserves, outside nature 
reserves, and in the entire TRSR were $7.30 \%, 5.05 \%$, and $6.16 \%$, respectively (Table 3 ).

Average annual vegetation coverage from 1990 to 2004 inside nature reserves was $5.57 \%$ more than that was outside, but increasing to $6.19 \%$ from 2005 to 2012 . In contrast, from 1997 to 2004, average annual NPP inside nature reserves was $46.02 \mathrm{~g} \mathrm{C} / \mathrm{m}^{2}$ higher than that measured outside, increasing to $58.86 \mathrm{~g} \mathrm{C} / \mathrm{m}^{2}$ higher from 2005 to 2012 (Table 4).

Data show that vegetation coverage in nine nature reserves, including Zhongtiejungong, Guozongmucha, Yueguzonglie, Zhalin-Erlin Lake, Xingxinghai, Nianbaoyuzhe, Geladandong, Animaqin, and Tongtianhe, decreased from 1997 to 2004 but increased from 2005 to 2012. Indeed, in the other nine nature reserves vegetation coverage increased both from 1997 to 2004 and from 2005 to 2012. Rates of increase in vegetation coverage in 13 nature reserves were higher than those recorded outside, and average annual NPP from 1990 to 2004 in all nature reserves increased compared with 2004-2012. Because increases inside nature reserves were higher than those recorded outside, comparisons show that this project has played a very important role in vegetation recovery across the TRSR, and that vegetation

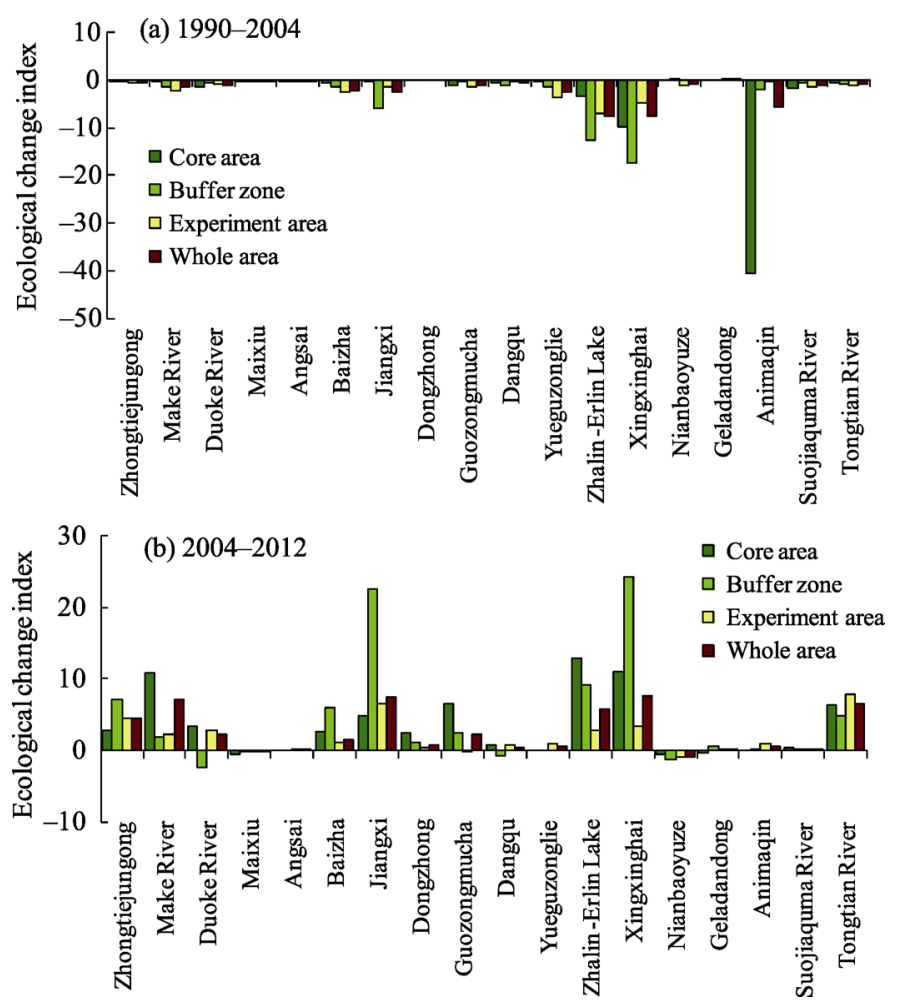

Figure 10 Ecological change indexes for nature reserves from 1990 to 2004 (a) and from 2004 to 2012 (b)

Table 3 Restoration areas of grassland, 2004-2012

\begin{tabular}{lcccc}
\hline \multirow{2}{*}{ Region } & \multicolumn{2}{c}{ Degraded grassland, 1990-2004 } & \multicolumn{2}{c}{$\begin{array}{c}\text { Obviously improved grassland, } \\
\text { 2005-2012 }\end{array}$} \\
\cline { 2 - 5 } & Area $\left(\mathrm{km}^{2}\right)$ & $\begin{array}{c}\text { Proportion of degraded } \\
\text { grassland in entire area (\%) }\end{array}$ & $\begin{array}{c}\text { Area } \\
\left(\mathrm{km}^{2}\right)\end{array}$ & $\begin{array}{c}\text { Proportion of degraded } \\
\text { grassland in each area }(\%)\end{array}$ \\
\hline Nature reserves & 43490.67 & 49.4 & 3173.00 & 7.30 \\
Outside nature reserves & 44591.40 & 50.6 & 2252.81 & 5.05 \\
The TRSR & 88082.07 & 100 & 5425.81 & 6.16 \\
\hline
\end{tabular}


Table 4 Comparisons of vegetation coverage and NPP inside, and outside, nature reserves before, and after, project implementation

\begin{tabular}{|c|c|c|c|}
\hline Period & Region & Vegetation coverage $(\%)$ & $\mathrm{NPP}\left(\mathrm{g} \mathrm{C} / \mathrm{m}^{2}\right)$ \\
\hline \multirow{3}{*}{ 1997-2004 } & Nature reserves & 47.15 & 246.86 \\
\hline & Outside nature reserves & 41.58 & 200.84 \\
\hline & $\begin{array}{l}\text { Difference between inside and } \\
\text { outside }\end{array}$ & 5.57 & 46.02 \\
\hline \multirow{3}{*}{ 2005-2012 } & Nature reserves & 50.34 & 306.23 \\
\hline & Outside nature reserves & 44.15 & 247.37 \\
\hline & $\begin{array}{l}\text { Difference between inside and } \\
\text { outside }\end{array}$ & 6.19 & 58.86 \\
\hline \multirow{3}{*}{$\begin{array}{l}\text { Difference between } \\
\text { former and latter periods }\end{array}$} & Nature reserves & 3.19 & 59.37 \\
\hline & Outside nature reserves & 2.57 & 46.53 \\
\hline & $\begin{array}{l}\text { Difference between inside and } \\
\text { outside }\end{array}$ & 0.62 & 12.84 \\
\hline
\end{tabular}

recovery inside nature reserves has been more remarkable than that seen in other regions (Figure 11).
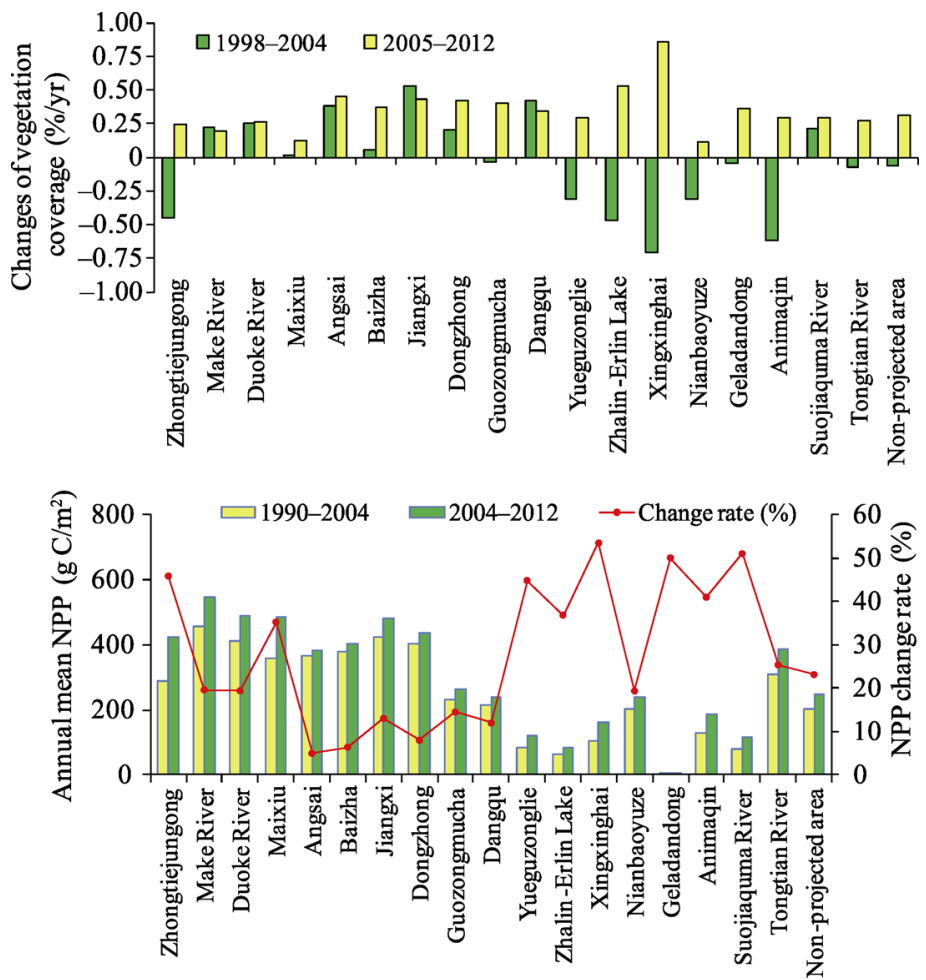

Figure 11 Changes in vegetation coverage and NPP in nature reserves before, and after, project implementation

\subsection{Attribution analysis of ecosystem changes}

\subsubsection{Effects of the ecological project on ecosystems}

On the basis of simulation results, climate change is a dominating influence on vegetation recovery in the TRSR. However, in the project area, and especially in the Yellow River Ba- 
sin, engineering techniques have actually made more of a contribution to ecosystem restoration.

Indeed, in key project areas, a number of different ecological restoration measures were implemented. Of these, the 'Restoring Grazing Land to Grassland Project' reduced the number of livestock in the project area, which decreased the grazing pressure index. In addition, the 'Black Beach Grassland Treatment Project' and the 'Rodent Control Project' helped to restore degraded grassland as well as to prevent the occurrence of new degradation. Artificial precipitation increased soil moisture and the area of lakes and wetlands, while the recovery of degraded grasslands and an increase in grassland productivity promoted water regulation and played an important role in ecology and production of downstream.

\subsubsection{Effects of climate change on ecosystems}

Temperature and precipitation in the TRSR both show a decreasing trend from southeast to northwest. Indeed, while temperatures in this region have continued to get warmer, precipi-tation has changed periodically; from 1975 to 2004, the climate in this region was getting warmer and drier. Average annual temperature and precipitation were $-0.58^{\circ} \mathrm{C}$ and $470.6 \mathrm{~mm}$, respectively, while their trends were $0.42^{\circ} \mathrm{C} / 10 \mathrm{yr}$ and $-9.3 \mathrm{~mm} / 10 \mathrm{yr}$, respectively. In contrast, from 2004 to 2012, the climate was getting warmer and wetter; average annual temperature and precipitation were $0.48^{\circ} \mathrm{C}$ and $518.7 \mathrm{~mm}$, respectively, and their trends were $0.19^{\circ} \mathrm{C} / 10 \mathrm{yr}$ and $68.4 \mathrm{~mm} / 10 \mathrm{yr}$, respectively (Figure 12 ). Temperatures rose most in the mid-east of the region, and least in the northwest, while precipitation showed a remark-able increase in the mid-west (Figure 13). Warming climate led to an advancing rate of vege-tation re-greening and melting of permafrost and glaciers increased runoff. Coupled with this increase in precipitation and runoff, water area increased, and vegetation began to experience a more favorable growing environment. These effects led to faster vegetation recovery and a decreasing rate of desertification.
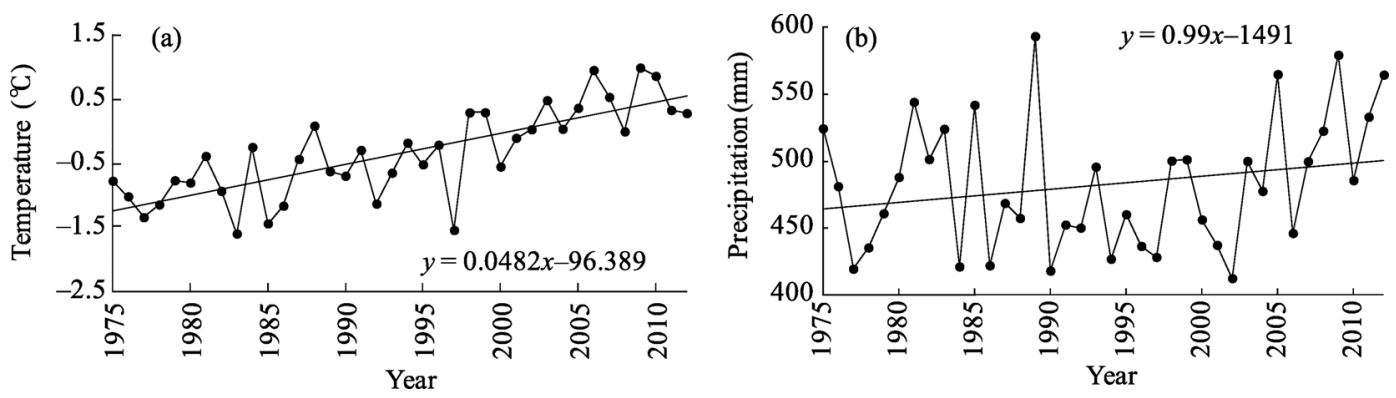

Figure 12 Variations in annual average temperature and annual precipitation in the TRSR, 1975-2012

\subsubsection{Contribution rates of the ecological project and climate change to ecosystem changes}

Under real, and average, climate conditions, changes in NPP were 21.79 and $13.49 \mathrm{~g}$ $\mathrm{C} / \mathrm{m}^{2} / \mathrm{yr}$ before, and after, the project; thus, the contribution rate of increasing NPP from the ecological project was $61.9 \%$, while it was $38.1 \%$ due to the influence of climate change. In contrast, water regulation changes under the two climate conditions were 2.222 billion and 534 million $\mathrm{m}^{3} / \mathrm{yr}$, respectively; thus, the contribution rate due to the ecological project was $24 \%$, while $76 \%$ was due to climate change. Water erosion changes under the two climate conditions were 2000 and $-1600 \mathrm{t} / \mathrm{yr}$; thus, the contribution rate of the ecological project to 
the increase in water erosion was $-80 \%$, while the influence of climate change was $180 \%$ (Table 5).
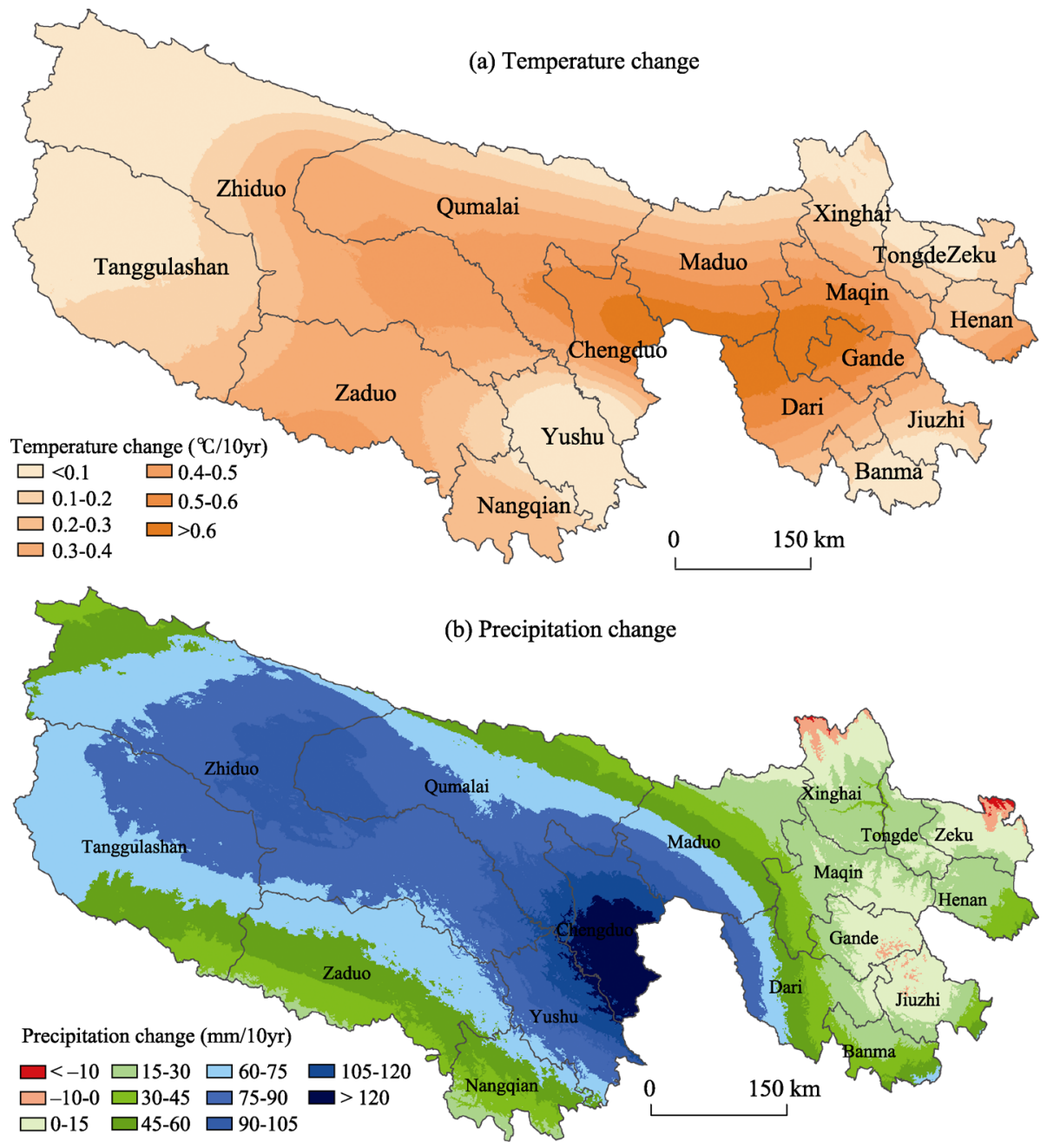

Figure 13 Variations in annual average temperature and annual precipitation in the TRSR, 2004-2012

Table 5 Evaluation indexes for 1997-2004 and 2005-2012 under real, and average, climate conditions

\begin{tabular}{|c|c|c|c|c|}
\hline \multirow{2}{*}{ Evaluation index } & \multicolumn{2}{|c|}{$\begin{array}{l}\text { Difference between 1997-2004 } \\
\text { and 2005-2012 }\end{array}$} & \multirow{2}{*}{$\begin{array}{l}\text { Contribution rate of } \\
\text { ecological project }\end{array}$} & \multirow{2}{*}{$\begin{array}{c}\text { Contribution rate } \\
\text { of climate } \\
\text { change }\end{array}$} \\
\hline & $\begin{array}{l}\text { Real climate } \\
\text { conditions }\end{array}$ & $\begin{array}{l}\text { Average climate } \\
\text { conditions }\end{array}$ & & \\
\hline $\mathrm{NPP}\left(\mathrm{g} \mathrm{C} / \mathrm{m}^{2} / \mathrm{yr}\right)$ & 21.79 & 13.49 & $61.9 \%$ & $38.1 \%$ \\
\hline Water conservation $\left(10^{8} \mathrm{~m}^{3} / \mathrm{yr}\right)$ & 22.22 & 5.34 & $24 \%$ & $76 \%$ \\
\hline Soil water erosion $(\mathrm{t} / \mathrm{yr})$ & 2000 & -1600 & $-80 \%$ & $180 \%$ \\
\hline
\end{tabular}

On the basis of these results, it is clear that vegetation recovery in the TRSR was actually affected by two factors: the ecological project, and climate change (i.e., precipitation increase and temperature rise). Although climatic factors before, and after, the project did not change under average conditions, vegetation parameters in the GLOPEM, RUSLE, and wa- 
ter regulation models could partly be influenced by climate change. Thus, the contribution rate of the ecological project might be overestimated; the method used to determine this contribution rate should be improved in future studies.

\section{Discussion and conclusions}

It is worth noting that coverage of the TRSR ecological conservation and restoration project actually only accounts for $40 \%$ of this region. Throughout the project, while the trend in grassland degradation was partially curbed, only $6.17 \%$ of degraded grassland obviously recovered, and grassland coverage improved rather than community structure. All-in-all, $68.52 \%$ of degraded grassland in this region remained unchanged, while some in the Yellow and Yangtze river basins remained degraded at the end of the project, especially in Maduo, Qumalai, the north of Chenduo, and the southeast of Zhiduo. Grassland degradation has thus not been radically curbed across the region as a result of this project.

Over the implementation period of this project, although grassland increased by 123.70 $\mathrm{km}^{2}$, this accounts for only $8.9 \%$ of the net loss in the 1970 s. In contrast, desert area decreased by $492.61 \mathrm{~km}^{2}$, accounting for $73 \%$ of the area that increased in the $1970 \mathrm{~s}$. Finally, because wetlands and water area increased by $287.87 \mathrm{~km}^{2}$, accounting for $76.7 \%$ of the area that was lost in the 1970 s, it can be argued that ecosystem recovery was not as good as it could have been.

While the runoff in the Yellow River Basin increased as a result of this project, observational data from Tangnaihai hydrological station shows that this is still at a lower level than it was in the 1970s and 1980s (Table 6). Indeed, because the continued increase in runoff recorded at the Tuotuohe hydrological station in the Yangtze River Basin is mostly the result of melting of permafrost and glaciers due to climate warming, this will be unsustainable over the long-term.

Indeed, implementation of this project has also not yet contained the increasing trend in soil erosion; compared with 1997-2004, annual average soil loss has increased by 15.7 million $\mathrm{m}^{3} / \mathrm{yr}$ at the end of this project. According to inter-annual variability in sediment concentrations recorded at each hydrological station (Figure 14), soil erosion generally showed an increasing trend from 2004 to 2012, most likely the result of grassland degradation. Thus, although vegetation coverage has increased markedly throughout the TRSR, soil erosion has still increased; this is likely because vegetation coverage is just one factor that

Table 6 Variations in annual runoff at the major control hydrological stations in the Yangtze and Yellow river basins $\left(10^{8} \mathrm{~m}^{3}\right)$

\begin{tabular}{ccccc}
\hline \multirow{2}{*}{ Period } & \multicolumn{2}{c}{ Yellow River Basin } & \multicolumn{2}{c}{ Yangtze River Basin } \\
\cline { 2 - 5 } & Tangnahai station & Jimai station & Zhimenda station & $\begin{array}{c}\text { Tuotuohe station } \\
\text { (data from May to October) }\end{array}$ \\
\hline $1975-1980$ & 221.21 & 46.26 & 115.85 & 4.85 \\
$1975-1990$ & 236.10 & 47.90 & 131.37 & 6.14 \\
$1975-2004$ & 200.65 & 39.87 & 124.29 & 7.52 \\
$1975-2011$ & 201.40 & 41.90 & 132.40 & 9.10 \\
$1991-2004$ & 165.20 & 31.26 & 116.20 & 9.11 \\
$1997-2004$ & 161.00 & 30.20 & 122.10 & 11.70 \\
$2004-2011$ & 197.90 & 47.30 & 161.30 & 13.10 \\
\hline
\end{tabular}


prevents soil erosion. Increasing vegetation cover can promote soil retention capabilities to some extent, but the recovery of the root layer is more important and occurs over much longer timescales.

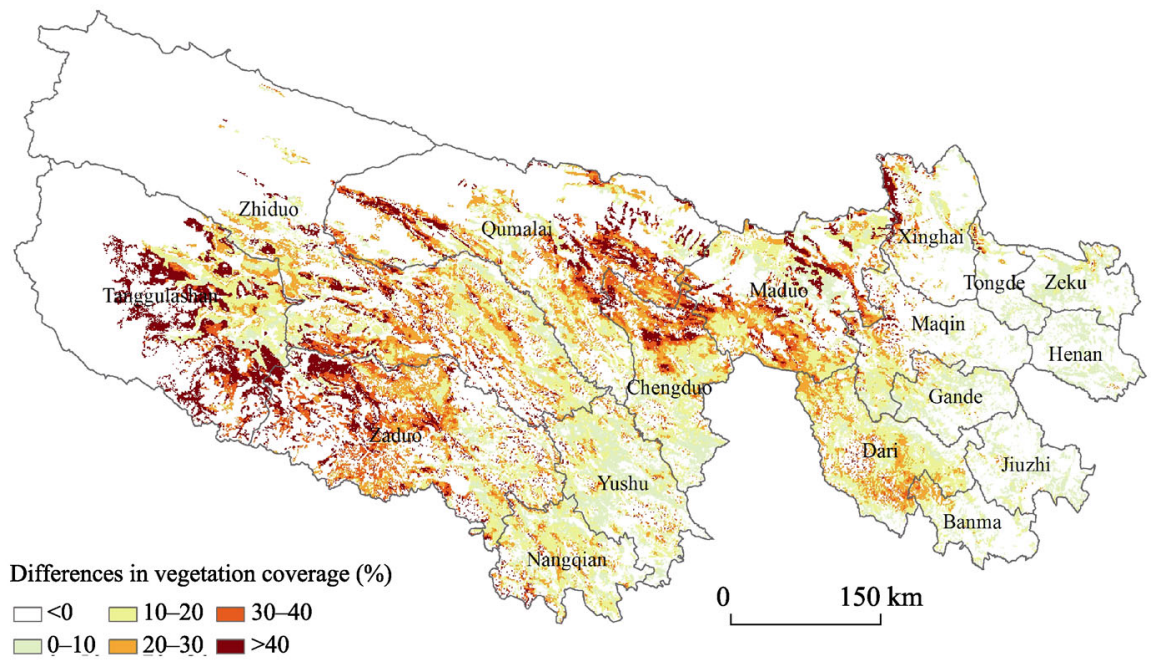

Figure 14 Differences in grassland vegetation coverage in the TRSR from 2005 to 2012 compared with the 1980 s

In sum, this first-stage project in the TRSR has been promising and effective in general; however, our studies also indicate that existing challenges to the ecological restoration of the TRSR still remain, and that a continued and long-term effort will still be needed.

To conclude, this study has comprehensively assessed the effects of the first phase of an ecological conservation and restoration project in the TRSR. Results lead to three main conclusions.

(1) Overall trends in ecosystem degradation have initially been contained; indeed, as a result of this project, ecosystem structure has gradually improved. For example, local water-body areas in the TRSR have been expanded, and some deserts have been converted into grasslands. Annual average vegetation coverage has remarkably increased, and the macro-ecological situation has improved, but still not to the levels of the 1970s. Indeed, the grassland degradation trend has been initially contained; this project has had a positive effect on improving grass coverage, but the natural characteristics of alpine meadows limit the rate of increase. In contrast, wetlands and water bodies have generally been restored in the region, while the capacity for water regulation and water supply have been improved, and the target of increasing water regulation volume has been achieved. River runoff into the Yellow River Basin shows that the target, a 1.2 billion $\mathrm{m}^{3}$ increase, has been achieved. In addition, soil retention capacity has been improved; indeed, the amount of soil retention continues to increase. However, the soil erosion targets in 'The Plan' have not been achieved, as erosion during the project period has increased by 20 million tons.

(2) Key project areas have experienced more improvements in their ecological situation than non-project areas and there is significant spatial heterogeneity. In addition to impacts due to climate, implementations of ecological protection and construction have had obvious, and positive, effects on promoting vegetation recovery inside nature reserves. Indeed, vegetation recovery and ecosystem improvements have enhanced ecosystem services as well as 
the quality of wildlife habitats. In terms of 'decreasing livestock and migrating people', the number of wild animals in this region has increased markedly, especially in the Yellow River Basin, and compared with non-protected areas, the NPP of grasslands inside nature reserves has also clearly increased. Therefore, the ecological conservation and restoration project has led to positive effects in addition to climate impact.

(3) Project effects can be summarized in terms of 'preliminary containment in degradation, partial improvement in recovery' within the TRSR. We found that climatic factors (including an artificial rain project) played a dominant role in vegetation restoration, while ecological projects also had a positive effect. Indeed, in the project region, especially key areas around the Yellow River Basin, the contributions of ecological projects to ecosystem restoration are more remarkable.

Overall, the ecological effects of this project are remarkable, and the objectives of 'The Plan' have been basically achieved.

\section{Acknowledgements}

The authors would like to thank Jinwei Dong for his help in writing this article as well as the anonymous reviewers for their constructive comments on the manuscript.

\section{References}

Abbot M, Dawson T, Clark J et al., 2015. NEON science capability assessment. http://www.neoninc.org.

Bing L F, Shao Q Q, Liu J Y et al., 2011. Runoff characteristics in flood and dry seasons in source regions of Yangtze River and Yellow River based on wavelet analysis. Scientia Geographica Sinica, 31(2): 232-238. (in Chinese)

Bing L F, Shao Q Q, Wang J B, 2012. Heterogeneity and error estimation of grassland biomass based on cyclic sampling approach. Acta Agrestia Sinica, 20(2): 257-267. (in Chinese)

Cai B F, 2009. Study on the Monitoring and Evaluation of the Three North Shelterbelt Project. Beijing: Chemical Industry Press. (in Chinese)

Chen Z Q, Shao Q Q, Liu J Y et al., 2012. Analysis of net primary productivity of terrestrial vegetation on the Qinghai-Tibetan Plateau, based on MODIS remote sensing data. Science in China (Earth Sciences). doi: 10.1007/s11430-012-4389-0. (in Chinese)

China National Environmental Monitoring Centre (CNEMC), 2004. Study on Ecological Environmental Quality Assessment China. Beijing: China Environmental Science Press. (in Chinese)

Fan J W, Shao Q Q, Liu J Y et al., 2010. Dynamic changes of grassland yield in the Three River Headwater Region from 1988 to 2005. Acta Agrestia Sinica, 18(1): 5-10. (in Chinese)

Fan J W, Shao Q Q, Wang J B et al., 2011. An analysis of temporal-spatial dynamics of grazing pressure on grassland in the Three Rivers Headwater Region. Chinese Journal of Grassland, 33(3): 64-72. (in Chinese)

Fryrear D W, Saleh A, Bilbro J D et al., 1998. Revised Wind Erosion Equation (RWEQ). Wind Erosion and Water Conservation Research Unit, Technical Bulletin 1, Southern Plains Area Cropping Systems Research Laboratory, USDA-ARS.

Gong G L, 2014. Research on the spatial-temporal changes of wind erosion in northern China and the influence factors [D]. Beijing: Chinese Academy of Sciences. (in Chinese)

Guo B, Zhou Y, Zhu J F et al., 2016. Spatial patterns of ecosystem vulnerability changes during 2001-2011 in the Three-River Source Region of the Qinghai-Tibetan Plateau, China. Journal of Arid Land, 8(1): 23-35.

Hu Y F, Liu J Y, Qi Y Q et al., 2010. Positivist analysis on the effects of ecological projects in the farming-pastoral transition belt of Inner Mongolia Autonomous Region. Geographical Research, 29(8): 1452-1460. (in Chinese)

Li S D, 2006. China Ecological Status Report 2005: Ecological Comprehensive Index \& Ecological Status Assessment. Beijing: Science Press. (in Chinese)

Li S D, 2007. World's Important Ecological Engineering. Beijing: Science Press. (in Chinese)

Liu J Y, Shao Q Q, Fan J W, 2009. The integrated assessment indicator system of grassland ecosystem in the 
Three-River Headwater's Region. Geographical Research, 28(2): 273-283. (in Chinese)

Liu J Y, Shao Q Q, Xu X L, 2008. The spatial and temporal characteristics of grassland degradation in the Three-River Headwater's Region in Qinghai Province. Acta Geographica Sinica, 63(4): 364-376. (in Chinese)

Liu J Y, Yue T X, Ju H B et al., 2006. Integrated Ecosystem Assessment in Western China. Beijing: China Meteorological Press. (in Chinese)

Liu Y, 2006. Study on post-evaluation of theory and application of the forest ecological engineering in China [D]. Beijing: Beijing Forestry University. (in Chinese)

Local Standard of Qinghai Province (LSQP), 2014. Technical Specification of Ecological Effects Assessment of Ecosystem Protection and Recovery Projects in Sanjiangyuan Region (DB63/T1342-2015).

Millennium Ecosystem Assessment (MEA), 2003. Ecosystems and Human Well-being. Washington: Island Press.

National Standards of the People's Republic of China, 2009. Evaluation in Project for the Construction of Conversion of Cropland to Forest (GB/T23233-2009). Beijing: Standards Press of China. (in Chinese)

Renard K G, Foser G R, Weesies G A et al., 1997. Predicting soil erosion by water: A guide to conservation planning with the Revised Universal Soil Loss Equation (RUSLE). Washington: US Department of Agriculture, Agricultural Research Service.

Shao Q Q, Liu J Y, Huang L et al., 2013. Integrated assessment on the effectiveness of ecological conservation in The TRSR National Nature Reserve. Geographical Research, 32(9): 1645-1656. (in Chinese)

Shao Q Q, Xiao T, Liu J Y et al., 2011. Soil erosion rates and characteristics of a typical alpine meadow using the ${ }^{137} \mathrm{Cs}$ technique in Qinghai-Tibet Plateau. Chinese Science Bulletin, 56. doi: 10.1007/s11434-011-4477-0. (in Chinese)

State Forestry Administration (SFA), 2014. National Report on the Ecological Benefits of Grain for Green Program in 2013. Beijing: China Forestry Publishing House. (in Chinese)

State Forestry Administration (SFA), 2015. Technical Specification on Evaluation of the Three North Shelterbelt Project (LY/T 2411-2015). Beijing: Standards Press of China. (in Chinese)

Sun W Y, Shao Q Q, Liu J Y et al., 2011. The variation characteristics of soil organic carbon of typical alpine slope grasslands and its influencing factors in the 'Three-River Headwaters' Region. Journal of Natural Resources, 26(12): 2072-2087. (in Chinese)

The Environmental Protection Industry Standard of People's Republic of China (EPIS PRC), 2006. Technical Criterion for Eco-environmental Status Evaluation (HJ/T 192-2006). Beijing: China Environmental Science Press. (in Chinese)

The People's Government of Qinghai Province (PGQP), 2005. The General Planning on Ecological Protection and Construction in the TRSR Nature Reserve, Qinghai Province. (in Chinese)

The H. John Heinz III Center for Science, Economics and the Environment, 2008. The State of Nation's Ecosystems 2008: Measuring the Lands, Waters, and Living Resources of the United States.

Vaughan H, Brydges T, Fenech A et al., 2001. Monitoring long-term ecological changes through the Ecological Monitoring and Assessment Network: Science-based and policy relevant. Environmental Monitoring and Assessment, 67(1/2): 3-28.

Wang J B, Liu J Y, Shao Q Q et al., 2009. Spatial-temporal patterns of net primary productivity for 1988-2004 based on GLOPEM-CEVSA model in the 'Three-River Headwaters' region of Qinghai Province, China. Chinese Journal of Plant Ecology, 33(2): 254-269. (in Chinese)

Wang L X, Wang B R, 2000. Forestry Ecological Engineering. Beijing: China Forestry Publishing House. (in Chinese)

Wu D, 2014. Research on water regulation service of the main terrestrial ecosystems in China [D]. Beijing: Chinese Academy of Sciences. (in Chinese)

Xiao W F, Huang Z L, Tang W P et al., 2012. Monitoring and Evaluation of Ecological Benefits of National Land Conversion Program in Three Gorges Reservoir Area. Beijing: Science Press. (in Chinese)

Xu X L, Liu J Y, Shao Q Q et al., 2008. The dynamic changes of ecosystem spatial pattern and structure in the Three-River Headwater Region in Qinghai Province during recent 30 years. Geographical Research, 27(4): 829-838. (in Chinese)

Xu X Q, 1992. Integrated Evaluation on Synthetically Efficiency of Forests. Beijing: China Forestry Publishing House. (in Chinese)

Yu X X, Gu J C, Yue Y J et al., 2010. Benefit Evaluation on Forestry Ecological Projects. Beijing: Science Press. (in Chinese)

Zhao Z P, Liu J Y, Shao Q Q, 2010. Characteristic analysis of land cover change in the Nature Reserve of the Three River's Source Region. Scientia Geographica Sinica, 30(3): 415-420. (in Chinese) 